\title{
Post-colonialism and Feminism
}

\author{
A. L. M. Riyal ${ }^{1}$ \\ ${ }^{1}$ Department of Social Sciences, Faculty of Arts and Culture, South Eastern University of Sri Lanka, Sri Lanka \\ Correspondence: A. L. M. Riyal, Department of Social Sciences, Faculty of Arts and Culture, South Eastern \\ University of Sri Lanka, Sri Lanka. Tel: 94-77-910-7456. E-mail: almriyal@seu.ac.lk
}

Received: September 5, 2019

Accepted: September 30, 2019

Online Published: October 24, 2019

doi:10.5539/ass.v15n11p83

URL: https://doi.org/10.5539/ass.v15n11p83

\begin{abstract}
Since the 1980s, feminism and post-colonialism began to exchange and dialogue, forming a new interpretation space, that is, post-colonial feminist cultural theory. There is a very complicated relationship between post-colonialism and feminism, both in practice and theory. It was obvious that they have always been consistent as both cultural theories focus on the marginalization of the "other" that is marginalized by the ruling structure, consciously defending their interests. Post-structuralism is used to deny the common foundation of patriarchy and colonialism - the thinking mode of binary opposition. However, only in the most recent period, Postcolonialism and feminism "Running" is more "near", it is almost like an alliance. (The factor contributing to this alliance is that both parties recognize their limitations.) Furthermore, for quite some time there have been serious conflicts between these two equally famous critical theories. They have been deeply divided on issues, such as how to evaluate the third world women's liberation, how to view the relationship between imperialism and feminism, and how to understand that colonialists use the standards of feminism to support their "civilization mission." This article has greatly benefited from the perspectives and materials of Leela Gandhi's Postcolonial Theory; A Critical Introduction.
\end{abstract}

Keywords: Post-colonialism, feminism, Colonialism, woman, western

\section{Introduction}

The most important disagreement was over "women in the third world". Some post-colonialists who hold feminist positions believe that focusing only on racial politics is bound to ignore the "double colonization" (both racial and gender) situation of women under imperialist conditions. This theory assumes that women in the third world are the dual victims of both indigenous and alien ideologies of patriarchal imperialism. In the view of feminists, anti-colonial nationalism in the third world also has serious gender discrimination, while the post-colonial theory shows serious theoretical blindness in this regard.

In the eyes of some post-colonial critics, the so-called "women of the third world" that western feminism is fond of talking about, particularly the emphasis on their "differences", is itself colonial. Wherever indigenous women go, western feminists demand that they show what they call "differentiation." This fascination with the colorful exoticism of native women only serves to satisfy the voyeuristic desire of western women. The consciousness of difference sets up an implicit cultural hierarchy: western feminists have the privilege of preparing the path to liberation for their "unfortunate sisters."

In "Under the eyes of the west: feminist scholarship and colonial discourse", first published in 1982, is frequently acknowledged as a significant postcolonial challenge to mainstream Western feminism. Postcolonial feminists writers Chandra Talpade Mohanty pointed out: "the third world woman" this analytic category in the two layers of meaning is the nature of colonialism. First, because it's ethnocentric myopia disregards the enormous material and historical differences between 'real' third-world women; and second, because the composite 'Othering' of the 'third-world woman' becomes a self-consolidating project for Western feminism (Gandhi's, 1998, pp. 85-86). In this way, western feminists produced a' double colonization' principally to contrast the political immaturity of third-world women with the progressive ethos of Western feminism. It is well known that woman of the third world are reproduce as 'ignorant, poor, uneducated, tradition-bound, domesticated, family-oriented, victimized', facilitates and privileges the self-representation of Western women 'as educated, modern, as having control over their bodies and "sexualities", and the "freedom" to make their own decisions' (Mohanty, 1994, p. 200). 
To a large extent, the above criticism of feminist imperialist tendency has absorbed Edward Said's understanding of the colonial discourse. In Edward Said's view, colonial discourse is the cultural prerogative to reproduce the conquered other. Both orientalists and feminists try to speak of the third world through a common dogma: This dogma insists: they cannot reproduce themselves; they must be reproduced. Thus, "women of the third world" can be seen as another "object" of western knowledge.

Gayatri Spivak's also challenges this feminist intellectual system of western liberalism. In the article "French feminism in an international frame", (1987) Spivak is known as the famous feminist Julia. Kristeva's "About Chinese Women" as the object of criticism, this article analyzes the narcissism of liberal feminists. Spivak points out that in Kristeva's text, Chinese women eagerly expected the speeches of French feminists, and there was a serious gap between the silence of Chinese women in the observation status and the discourse hegemony of feminists in the observation status.

We have never heard the voice of Chinese women. Spivak says that "on the face of those silent women, her (Kristeva's) problem is not so much related to her, but with her own identity" (Spivak, 1987, p. 137). Spivak's deconstructive reading is questioning the "epistemological violence" of these first-world feminists, which makes them the authoritative subject of knowledge, while Chinese women become passive and deprived of the right to speech.

Spivak profoundly points out that "Women on China" is a book about Kristeva's own; it only calls the differences of women in the third world as the raw material of Western theory. The material and historical stage presented in front of Kristeva is just a self-confirmation opportunity. The interest of these feminist critics in the western or capitalist "other" (third world women) is undoubtedly self-centered. In this sense, they were simply complicit in colonialism, a form of neo-orientalism.

According to Edward Said, orientalism is a hegemonic discourse that constructs or orientates the east for imperialism. Feminism is undoubtedly part of the colonial knowledge-discourse system in the construction of third-world women as an undifferentiated "other" (Said, 1977, pp. 162-206).

As Mohanty suggests, "without the overdetermined discourse that creates the third world, there would be no (singular privileged) first world" (Mohanty, 1988, p. 82). Without 'women of the third world', the special self-representation of western women would be problematic. Therefore, there is a shadow of imperialism in the feminist studies that essentializes the difference/particularity of the "other" of local women.

In the eyes of the post-colonial critics, the root of the mistake lies in the represent or representative privilege claimed by hegemonic western feminist discourse. The western feminists who flaunted freedom and scholarship deprived the third world women of their voice when they spoke for them in a self-righteous and dignified way. Spivak's original essay can the subaltern talk? (Spivak, 1988, pp. 271-313). This important article delves into the complex relationship between being the subject of the study (in this case western feminist critics) and being the subject of the study (in this case, women in the third world). "How can we reach people's consciousness?" she asked. What kind of voice can untouchables speak through - consciousness? Spivak places us in the familiar and difficult territory of representation and reproducibility.

How can historians and researchers avoid the inevitable risk: seeing themselves as authoritative representatives of the people's consciousness? Should intellectuals give up representation? What kind of intellectual is qualified to represent what kind of people? Are there untouchables who cannot be represented but who know them and speak of themselves? Who are the true or representative pariahs (especially in the frame of reference provided by the imperialists)? Spivak profoundly points out that the gendered subaltern disappears because we have never heard her speak about herself. She is simply the medium through which competing discourses represent their claims; a palimpsest written over with the text of other desires, other meanings (Gandhi's, 1998, p. 90). Spivak earlier essay, 'Three women's texts and a critique of imperialism' (1985), it also discusses the absence of women from the third world in liberal feminist discourse. This article shows the core of the conflict between post-colonial criticism and feminist criticism. The article points out that women in the third world are notably absent from the literature that celebrates the emergence of western female subjects (Spivak, 1985, pp. 242-261).

Spivak said that the ideal female image of Western feminism is based on the individualistic values of Western liberalism. The re-reading of women's history shows that western feminist historical movements define themselves according to such individualistic women. Academic research on feminism never considers where the battlefield of female individualism is, nor does it care about a large number of women who have been sacrificed and excluded in connection with the "achievements" of individual liberal individualists. Spivak's article is posed as an attempt to uncover the repressed or forgotten history of Euro-American feminism. Once again the margins reveal the mute figure of gendered subalternity: As the female individualist, not quite/not male, articulates 
herself in shifting relationship to what is at stake, the "native female" as such (within discourse, as a signifier) is excluded from any share in this emerging norm (Ibid, pp. 244-245).

Feminist individualists express themselves concerning centers and powerful forces, and local women are excluded from the emergence of norms about women. In the analysis of Jane Eyre, Spivak puts this text highly praised by western feminism into the context of the era of European imperialism, and pointed out that the cultural and literary production in Europe in the 19th century could not get rid of the history and achievements of the imperialist plan. Therefore, as long as feminists look for the source of inspiration in this period, it must have the characteristics of the imperialist discourse.

However, the above criticism of western liberalism feminism also has limitations. They did essentially idealize the epistemological opacity of "real" third world women. In their opinion, women in the third world are always outside the scope of western analysis, and they are a completely different carrier of meaning and experience from the west. However, in doing so, these critics paradoxically reinvested third world women with the iconoclasm they had begun to break. This newly recovered image is now assumed to be the triumphal field of anti-colonial resistance. This is a reversed ethnocentrism, which is not fundamentally different from the overall thought of orientalism criticized by Saids.

In this context, to address this long-felt gap, this paper explores the relationship between Post-colonialism and feminism.

\section{Methodology}

The critical analytical method which is conducted to provide a better understanding of writing is used in this study. Using qualitative research and grounded theory, it is hoped to explore important facts related to the concepts of Post-colonialism and feminism explained in this article. Using a descriptive research method, identified elements of Post-colonialism and feminism were discussed in detail for the depth understanding of the concepts.

\section{Findings and Discussion}

The following section contains the main idea of the paper that critiques the existing theory of feminism and post-colonialism.

\subsection{The Veil of Algerian Women}

In spite of the criticism of the liberal feminist tendency of western centralism and imperialism, post-colonial criticism seems plausible, however, in the fight against the liberal feminism, post-colonial eventually cannot solve "feminist emancipation" and "cultural emancipation" of tension between the two demands. As Kirsten Holst Peterson points out, it cannot solve the question of which is more important, which comes first, the fight for female equality or the fight against Western cultural imperialism? (Holst Peterson in Ashcroft et al., 1995, p. 252). If feminism of contemporary liberalism is at least partly "born" from imperialism, then post-colonialism often sets the anti-colonial struggle against the liberation of women in the third world against each other, which makes the dual opposition between feminism and post-colonialism.

In his book "A Dying Colonialism", 1965 in the book, Frantz fanon the veiled Algerian woman) assumption for Colonialism and an anti-colonial struggle between sites, in turn, The critique of Algerian patriarchy is read as a strategic attempt to fragment the unity of national revolution. The coloniser, Fanon tells us, destructures Algerian society through its women: 'If we want to destroy the structure of Algerian society, its capacity for resistance, we must, first of all, conquer the women; we must go and find them behind the veil where they hide themselves and in the houses where the men keep them out of sight' (Fanon, 1965, pp. 57-58).

Fanon's rhetoric consciously politicizes the veil of women, redefining colonialism as the project of 'unveiling Algeria'. Nationalists, on the other hand, appreciate and defend the veil as a symbol of native nationality and a metaphor for political resistance to western colonialism. Women in Algeria could become partners in the anti-colonial nationalist revolution only by saying "no" 'to the colonizer's 'reformist' invitation (Ibid p. 50). Farnon asked Algerian women to be loyal to their nation and resist the temptation of western liberal feminism. This shows fanon's anxiety about women's liberation from the nationalist standpoint. Spivak sums up this anxiety as: "White men are saving brown women from brown men" (Spivak, 1988 [1985], p. 296). In the understanding of the farmers, brown's "love" of compatriots must take precedence over white feminist invaders of the corrosion resistance of the women's liberation appeal - "sisters love". In other words, Algerian women's greatest contribution to the struggle against colonialism was their restraint on themselves and their acceptance of the oppressive fate of their "fellow-countrymen" with brown men. On the contrary, if they listen to the western feminists and demand the equal rights of men and women, they will become the scum and traitor of their nation. 
The book Mother India (1928 initial edition, 1986 re-edition) by American author Katherine Mayo gives a detailed description of the tragic fate of Indian women, domination, and brutishness of Indian men, the horrors of child marriage, the abjection of widowhood, etc., and proves that Indians lack the ability to govern themselves based on the uncivilized and rude attitude of men towards women.

As soon as the book was published, it was strongly criticized. Books such as "Father India: A Reply to Mother India", "A Son of Mother India Answers and Unhappy India" were published successively, denouncing "Mother India" as an excuse for colonial rule. And some of the anonymous authors, like Sister India, think that Mayo's criterion for feminism is foreign, not for India. They use the rhetoric of cultural authenticity to argue that the liberation of women in India must be expressed in the native language and that the women's liberation program recommended by Mayo is bound to fail because it makes Indian women poor copies of their western counterparts. It is India's disaster that if women in India replicate or imitate western women in that original way. Indian women will progress in their way. "We are by no means prepared to think that the Western woman of today is a model to be copied. What has often been termed in the West as the emancipation of women is only a glorified name for the disintegration of the family (Hackett \& Haslanger, 2006, pp. 476-477). Here, the west's feminism is not only demonized, but it also shows that the Indian nation has made its unique cultural identity through its women.

India sisters, such as books to worry about is the mother of India, a book would lead to national (spirit) of family life administrator (women) to imitate the west, bringing Europe bacteria to the basic unit of the Indian society family. Partha Chatterjee's recent book, 'The Nation and Its Fragments 1993', argues that according to the "authenticity" of women in India nationalism investment leads to a new enemy - Memsahib (India) for western women. In this way, Memsahib must be demonized to establish the difference between Indian women and western women. In the anxiety about the nationalism of "feminism" in the west, we can find the historical roots of post-colonialism's hatred of liberal feminism. Nationalist positions on women's issues led to the confrontation between 'brown men' and 'white women'. E. M. Forster in his "A Passage to India" makes this historic rivalry all the more remarkable. In this film, local men and western women are hostile to each other.

\subsection{Colonialism and Sexism}

During the recent years, a small but important group of critics has emerged and have attempted to reinterpret colonial encounters or conflicts between colonizers and colonized persons as a struggle between two opposing and intertwined forms of male centrism. In this kind of struggle, women in the colonial master country and women in the colonized country became the victims and symbolic intermediaries of the struggle between the opposing men, and also the objects they used together.

If anti-colonial nationalism turns itself into reality through the "female administrator" of spiritual family life, then the imperialist ethics of men also extract the essence of their "mission of civilization" through the "female angel" image in their country. In her recent book, "Imperial Leather, Race, Gender and Sexuality in the Colonial Contest," 1995, Anne McClintock analyzed the empire's investment in its women, she wrote, "Controlling women's sexuality, exalting maternity and breeding a virile race of empire-builders was widely perceived as the paramount means for controlling the health and wealth of the male imperial body" (McClintock 1995, p. 47). Other writers have also drawn attention to the colonial civilizing mission represented itself through the self-sacrificing, virtuous and domesticated figure of the 'white' housewife. The figure of woman, Jenny Sharpe argues, was instrumental in shifting a colonial system of meaning from self-interest and moral superiority to self-sacrifice and racial superiority (Sharpe, 1993, p. 7).

In this context, the research of McClintock et al. excavates the hidden aspects of gender antagonism. She believed that the masculinity of empire was articulated, in the first instance, through the symbolic feminization of conquered geographies, and in the erotic economy of colonial 'discovery' narratives (Hackett \& Haslanger, 2006, p. 478). For example, the myth about the development of Virginia is the same "with the male naming privilege, the white male made American identity an extension of his identity, placing the male European territorial privilege above her (new world) body and the fruits of her land."

Fanon's black skin, white mask in the passage indicates that how the loss of territory/gender anxiety produce corresponding with men in the colonial territory/gender regain fantasy: "I marry white culture, white beauty, white whiteness. When my restless hands caress those white breasts, they grasp white civilization and dignity and make them mine" (Fanon, 1967, p. 63). In this way, the conflict between territory and desire is expressed through the language of gender. In the colonized countries, such as India, western rulers are just like white men who rape Indian women, so they are also the targets of sexual revenge of Indian men. The rape of British women in India by Indian men is also mixed with a nationalist urge to return to the territory. In East and the west 
invaders against discourse, also can be found: rape women is not only a sign of colonial conquest, and motivate the anti-colonial struggle of one of the most important powers (express nationalism revenge desire of text is always highlight the imperialists repeatedly the animalistic behavior) for East women.

Fanon exploration, in "Black skin, white mask" also deals with the relationship between the colonial conflict and gender in Algeria. The study leads the author to conclude that the colonized man is the 'real' other for the colonizing white man (Hackett \& Haslanger, 2006, p. 479). Some scholars have applied this view to India, pointing out that colonized men defined their masculinity by referring to the so-called effeminacy of Indian men, and then demonstrated the rationality of colonization.

British historian Thomas Macaulay pointed out that in the eyes of colonial men, "Bengal's physical organs are weaker than women's. He lives in a steam-filled bath." Thus, by feminizing non-western men, the logic of colonialism was legitimized. In other words, India can and should be colonized because it lacks real men. This fully shows the homogeneity and homology between gender domination and colonial politics. Men's "natural" advantage over women corresponds directly to western advantage over non-western advantage. The indisputable domination of European men in suzerainty and colonial countries was expressed as extreme masculinity.

As Ashis Nandy pointed out in "Intimate Enemy: Loss and Recovery of Self Under Colonialism" (1983), Colonialism, too, was congruent with the existing Western sexual stereotypes and the philosophy of life which they represented. It produced a cultural consensus in which political and socio-economic dominance symbolized the dominance of men and masculinity over women and femininity (Nandy, 1983, p. 4).

\section{Conclusion}

Post-colonialism and feminism differ on some important issues, in my point of view because they are essentially the rights of a mass of ideological appeal (whether this group is the "third world" or "female"), and as a group, they inevitably exist to their group or other groups the tendency of the nature, consciously form different degree zones of color (need) to struggle. "Third world" or "female" in the post-colonial criticism and feminist criticism eliminated the difference between the concepts of the nature of socialism (monolithic) while ignoring the "third world" or "female". Also the "first world" and "male" are full of intrinsic differences. There is no difference in the "third world" (as well as the "first world") or "women" (and "male").

The concept was invented to combat the need. Compared to this group appeal, the concept of individualism seems more realistic. From the standpoint of individualism, the freedom and independence of individuals are most important and the existence of individuals is the real. Therefore, no matter what the group appeal in the name is, as long as it obscures or suppresses the existence, freedom, and rights of individuals, it must fight against it.

It is a very clear fact that the oppression of women can come from within women, and the oppression of the third world can come from within the third world, and likewise, men are not all oppressors of women, and the first world is all oppressors of the third world. If we stick too closely to the essentialist concept of groups, it is not easy to find or recognize such facts. ""Women," "men," "the third world," and "the first world" are all made up of specific individuals, and these individuals are necessarily different rather than monolithic". At the same time, "some feminist critics are less aggressive than they used to be, claiming that men can't have women, and that male writers, even Shakespeare, had a prejudice against the women he wrote about. They're starting to speak for male writers now." I think that, in both post-colonial feminism, as the movement for the emancipation of their goals should thoroughly eliminate the binary confrontation of logic, rather than in a reverse way, from slave to general) copy this logic, is to cancel the gender confrontation between men and women rather than in a different way of continuing of the confrontation. Moreover, the premise of doing so is to go back from the feminist position to the individualistic position and resist the oppression of both men and women.

\section{References}

(1967). Black Skin, White Masks (trans. Charles Lam Markmann). New York: Grove Press.

(1987). Essays in the Other World: Essays in Cultural Politics. New York: Routledge.

1988 [1985]. Can the subaltern speak? Reprinted in C. Nelson, \& L. Grossberg (Eds.), Marxist Interpretations of Culture. Basingstoke, Macmillan Education.

Fanon, E. (1965). A Dying Colonialism (trans. Haakon Chevalier). New York: Grove Press.

Gandhi's, L. (1998). Postcolonial Theory: A Critical Introduction. Australia: Allen \& Unwin.

Hackett, E., \& Haslanger, S. A. (2006). Theorizing Feminisms: A Reader. London: Oxford University Press. 
Mcclintock. (1995). Imperial Leather: Race, Gender and Sexuality in the Colonial Contest. London. Rutledge.

Mohanty, C. T. (1994). Under Western Eyes: Feminist Scholarship and Colonial Discourses. In P. Williams, \& L. Chrisman (Eds.), Colonial Discourse and Postcolonial Theory. New York: Columbia University Press.

Nandy, A. (1983). The Intimate Enemy: Loss and Recovery of Self Under Colonialism. Delhi: Oxford University Press.

Nelson, C., \& Grossberg, L. (Eds.) 1988 [1985]. “Can the subaltern speak?” reprinted in Marxist Interpretations of Culture. Basingstoke, Macmillan Education.

Peterson, K. H. (1995). First Things First: Problems of Feminist Approach to African Literature. In B. Ashcroft, G. Griffiths, \& H. Tiffin (Eds.), The Post-Colonial Studies Reader. London: Rutledge.

Said, W. (1977). ORIENTALISM. The Georgia Review, 31(1).

Sharpe, J. (1993). Allegories of Empire: The Figure of Woman in the Colonial Text. Minneapolis University of Minnesota Press.

Spivak, G. (1985). Three women's texts and a critique of imperialism. Critical Inquiry, 12.

\section{Copyrights}

Copyright for this article is retained by the author(s), with first publication rights granted to the journal.

This is an open-access article distributed under the terms and conditions of the Creative Commons Attribution license (http://creativecommons.org/licenses/by/4.0/). 